E International

The Fantasy World

of Private Finance for Transport

via Public Private Partnerships

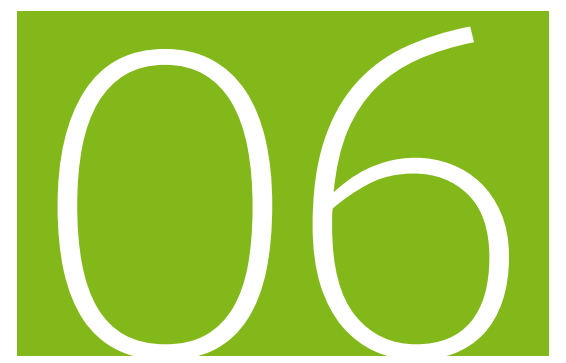

Discussion Paper 2012 06

Jean Shaoul, Anne Stafford and Pam Stapleton

Manchester Business School,

University of Manchester, UK 


\title{
The Fantasy World \\ of Private Finance for Transport via Public Private Partnerships
}

\author{
Discussion Paper No. 2012-6
}

Prepared for the Roundtable on:

Public Private Partnerships for Funding Transport Infrastructure:

Sources of Funding, Managing Risk and Optimism Bias

(27-28 September 2012)

\section{Jean SHAOUL, Anne STAFFORD \\ and Pam STAPLETON}

Manchester Business School,University of Manchester, United Kingdom

September 2012 



\section{INTERNATIONAL TRANSPORT FORUM}

The International Transport Forum at the OECD is an intergovernmental organisation with 54 member countries. It acts as a strategic think tank with the objective of helping shape the transport policy agenda on a global level and ensuring that it contributes to economic growth, environmental protection, social inclusion and the preservation of human life and well-being. The International Transport Forum organizes an annual summit of Ministers along with leading representatives from industry, civil society and academia.

The International Transport Forum was created under a Declaration issued by the Council of Ministers of the ECMT (European Conference of Ministers of Transport) at its Ministerial Session in May 2006 under the legal authority of the Protocol of the ECMT, signed in Brussels on 17 October 1953 , and legal instruments of the OECD.

The Members of the Forum are: Albania, Armenia, Australia, Austria, Azerbaijan, Belarus, Belgium, Bosnia-Herzegovina, Bulgaria, Canada, Chile, China, Croatia, the Czech Republic, Denmark, Estonia, Finland, France, FYROM, Georgia, Germany, Greece, Hungary, Iceland, India, Ireland, Italy, Japan, Korea, Latvia, Liechtenstein, Lithuania, Luxembourg, Malta, Mexico, Moldova, Montenegro, Netherlands, New Zealand, Norway, Poland, Portugal, Romania, Russia, Serbia, Slovakia, Slovenia, Spain, Sweden, Switzerland, Turkey, Ukraine, the United Kingdom and the United States.

The International Transport Forum's Research Centre gathers statistics and conducts co-operative research programmes addressing all modes of transport. Its findings are widely disseminated and support policymaking in Member countries as well as contributing to the annual summit.

\section{Discussion Papers}

The International Transport Forum's Discussion Paper Series makes economic research, commissioned or carried out at its Research Centre, available to researchers and practitioners. The aim is to contribute to the understanding of the transport sector and to provide inputs to transport policy design. The Discussion Papers are not edited by the International Transport Forum and they reflect the authors' opinions alone.

The Discussion Papers can be downloaded from:

\section{www.internationaltransportforum.org/jtrc/DiscussionPapers/jtrcpapers.html}

The International Transport Forum's website is at: www.internationaltransportforum.org

For further information on the Discussion Papers and other JTRC activities, please email:

\section{itf.contact@oecd.org}

This document and any map included herein are without prejudice to the status of or sovereignty over any territory, to the delimitation of international frontiers and boundaries and to the name of any territory, city or area. 


\section{TABLE OF CONTENTS}

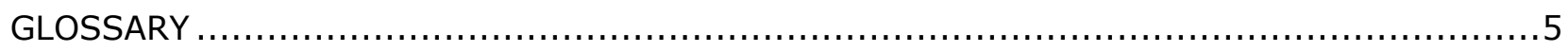

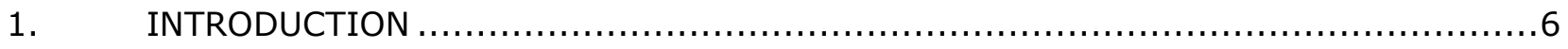

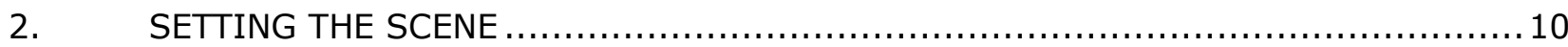

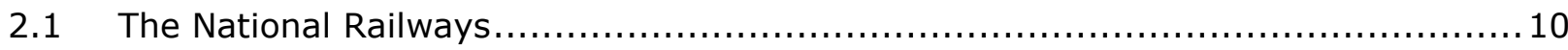

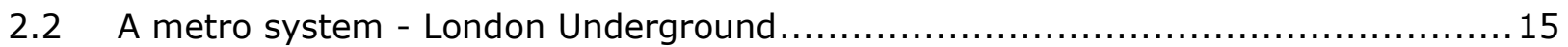

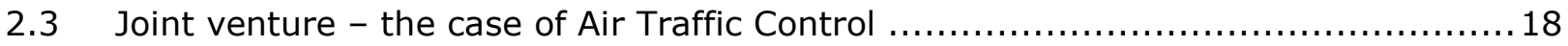

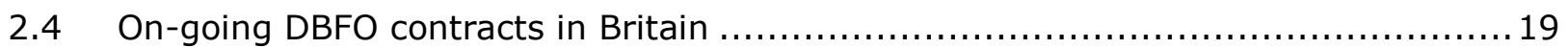

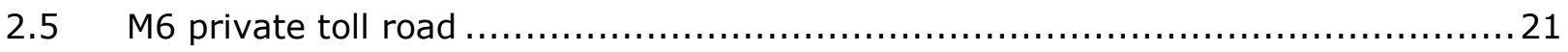

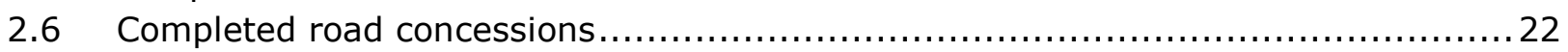

2.7 Proposed new bridge: The New Mersey Gateway ................................. 24

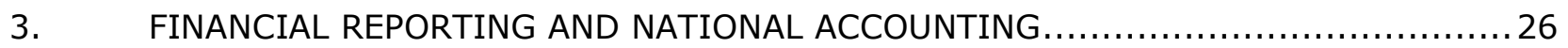

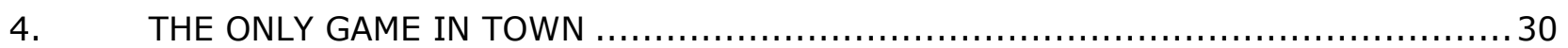

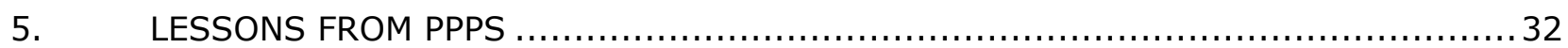

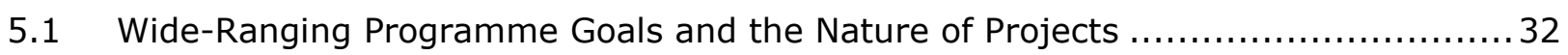

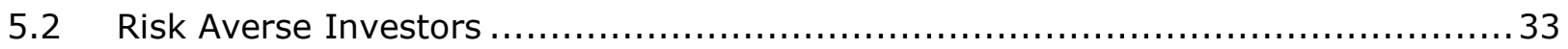

5.3 Risk Transfer, Risk Premiums and Evidence of Risk Transfer ........................ 34

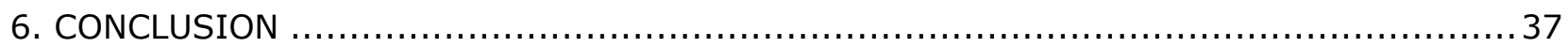

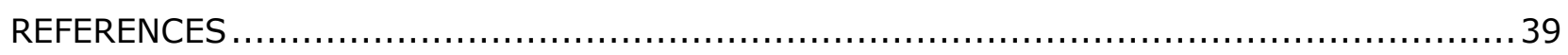




\section{Address for correspondence:}

Professor Pam Stapleton

Department of Accounting and Finance

Crawford House

University of Manchester

Manchester M13 9PL

Email: pam.stapleton@mbs.ac.uk

4 Jean Shaoul, Anne Stafford and Pam Stapleton- Discussion Paper 2012-6 - (C) OECD/ITF, 2012 


\title{
GLOSSARY
}

\author{
ATC Air Traffic Controller \\ BR British Rail \\ CAA Civil Aviation Authority \\ DBFO Design build finance and operate \\ DfT Department for Transport \\ ECML East Coast Main Line \\ LU London Underground \\ NA National Accounts \\ NAO National Audit Office \\ NATS National Air Traffic Services \\ NPV Net present value \\ PFI Private Finance Initiative \\ PPP Public Private Partnerships \\ PSC Public Sector Comparator \\ SBL Skye Bridge Limited \\ SPV Special Purpose Vehicle \\ SRA Strategic Rail Authority \\ TfL Transport for London \\ TOC Train operating company \\ VAT Value added tax \\ VFM Value for Money \\ WCML West Coast Main Line \\ WGA Whole of Government Accounts
}




\section{Introduction}

In 1993, the British government turned to the private sector to finance much needed investment in public infrastructure and manage services under its Public Private Partnerships (PPP) policy (Edwards et al., 2004), with transport forming by far the largest component by value of the PPP programme. Transport projects in Britain have typically taken one of a number of forms, including:

- A contractual type arrangement: the public sector pays for the use of the asset and its dependent services under terms set out in a contract, which may contain incentives for good and/or penalties for poor performance. Such contracts are usually designated as Private Finance Initiative (PFI) projects or design build finance and operate (DBFO) projects in the roads sector. Examples include the main trunk roads, where the public agency commissions the private sector to enhance, operate and maintain roads, paying for them on the basis of usage under a system known as shadow tolls.

- A free-standing project or concession: the private sector designs, builds finances and operates a road, but typically a bridge or a crossing, and charges the users directly (toll charge), as for example a number of estuarial crossings and Britain's first private toll road, the M6 toll road.

- An alternative freestanding project or concession: there is both public and user funding for either the construction and/or the service element. One example is the Skye Bridge where the Scottish Office paid some of the construction costs and later the Scottish Executive subsidised the tolls before ultimately terminating the contract. Another is the London Underground PPP, a contractual arrangement, where the public authority, London Underground, pays the private sector partner to upgrade and maintain the infrastructure, but receives a grant from central government, in effect a subsidy to the private sector, and charges passengers.

- A joint venture (joint ownership) arrangement: the partnership may charge either the public sector as in health and education, or the users (National Air Traffic Services). 
Partnership arrangements have become ever more complex and include a proliferating number of hybrids and pre-existing formats 1.

Nevertheless, there are normally important similarities. The public authority will contract with a Special Purpose Vehicle formed specifically to deliver one project. It will raise the finance the vast majority of which will take the form of senior debt (or prior to the credit crisis bond debt) often as much as $90 \%$ with the majority of the balance being subordinated debt. A tiny amount of equity, often referred to as pin point equity, will be provided by the SPV's owners. Related companies, legally separate subsidiaries, will contract to deliver the construction and services elements of the project.

In the UK the various PPP arrangements normally have one common and apparently attractive financial aspect. They enable the delivery of infrastructure without the need for the government to find a lump sum up-front, since finance is provided by the private sector. This defers expenditure - a politically attractive option. The private sector makes an annual charge over a period of at least 30 years, so that PPP projects require a revenue stream to pay these charges, which will be a function of the size of the initial investment (typically large), usage, operating costs (typically relatively low), the cost of finance and the period of the loan. That is, the revenue must enable recovery of the full costs over the life of the project, including debt and equity costs.

To understand the realities of PPPs a distinction between financing and funding must be made. Although the finance for the capital expenditure comes largely from the private sector, the funding to service the costs of the project comes from either the public sector or users. This can be illustrated by comparing private finance under PPP with buying a house with a mortgage. The prospective homeowner finances the transaction with a loan from a bank or financial institution, and funds the interest payments and repayments from monthly income. In other words, the bank provides the finance, but the owner funds it. Furthermore, over the 30 year period of the loan, the total cash payments are typically at least four if not five times the actual purchase price. A PPP is no different: the finance comes from a bank but the funds come from the public authority via taxation or the user via user charges.

A key message of this paper is that it is more costly for the public sector to use the private sector as financial intermediaries. This is due in part to the higher cost of commercial over public debt and the cost of the profit margin of both the private partner and its extensive supply chain. But there are also the not inconsiderable legal and financial advisors' fees to each of the numerous parties to the transaction to structure and negotiate $i t^{2}$.

1. For example, the UK government now calls the fragmented and privatised railways, various parts of which receive extensive capital grants, operating subsidies and debt guarantees, a public private partnership (DfT, 2004). The terminology is also used interchangeably, for example PFI is used to denote free standing projects and PPP is used in the case of London Underground to denote a contractual arrangement.

2. In the case of the flagship London Underground PPPs, advisors' fees amounted to $£ 500 \mathrm{~m}$.

Jean Shaoul, Anne Stafford and Pam Stapleton- Discussion Paper 2012-6 - (C) OECD/ITF, 2012 
The higher cost of capital under private finance is particularly important in the context of transport, where the capital as opposed to the operating cost is typically high and demand is rarely sufficient to recover costs. Demand may be high on individual routes but inadequate over the network as a whole.

For example, individual rail services, particularly the highly frequented inter-city and commuter lines may make a profit, but branch, feeder and off peak services, even on heavily trafficked routes, do not. Similarly, the national airlines are finding that the low cost operators have eaten into their frequent, short haul services, leading them to cut down on regional hubs and feeder services, leaving them highly vulnerable. In the case of roads, while high volume routes can be repaid within a relatively short period, political constraints may dictate low user charges or tolls spread over a longer period. Should however traffic flows be low or lower than predicted, then trains, roads and bridges will operate below capacity, making them difficult to fund, necessitating some combination of higher user charges, capital grants and public subsidy.

Transport projects are simply too capital intensive and thus financially risky, particularly since such services have never been sufficiently cash generative, if they are cash generative at all, to be run on a commercial, and geographically comprehensive basis. This is why the state has usually provided them. In order therefore to make such projects financially viable and attractive to the private sector, the government must ensure some combination of:

- capital grants or subsidies;

- implicit or explicit underwriting of the private sector's debt or the public authority's payments;

- bundling together of projects to increase their size relative to transaction costs.

Projects tend to be new build rather than refurbishment and in relation to publicly financed schemes a combination of the following is typical, especially when financing difficulties arise:

- $\quad$ project and service downsizing;

- higher charges for the public authority or the users; and

- a reduction in workers' jobs, wages and conditions.

All this has the potential to distort a capital prioritisation programme based upon an economic and social cost benefit analysis in favour of schemes that can be made to generate the requisite cash flows. Should income flows post-implementation turn out to be lower or costs higher than expected for the public agency, then a privately financed project must come at the expense of other services, further distorting rational resource allocation. But should the private partner find that its income is less than expected or costs higher, then it will either seek ways of increasing its income - typically by high charges for the inevitable changes to the original contract over its 30 year life - or hand back the keys.

In Britain, the policy and the inevitably higher cost of private finance is justified in terms of delivering value for money (VFM), an intuitively plausible but ambiguous concept. It is measured by comparing the discounted whole life costs with conventional procurement as reflected in a public sector comparator (PSC), which includes the cost of the risks transferred 
to the private sector. In order to proceed with capital investment under PPP, the public authority must demonstrate that the project is likely to deliver VFM over the life of the project and be affordable. That is, VFM rests upon estimates of costs for future services and risks which are at best uncertain over a long period, and is equated with economy.

It is also generally assumed that the private sector will be able to deliver the service at a lower cost due to the private sector's presumed greater efficiency, although there is no well evidenced basis for this as others have noted (see Hall and Lobina, 2005; IMF, 2004, to cite but two). VFM is an inherently ex ante concept as risks, and thus the cost of risk, cannot be adequately measured after implementation. In practice, since the public authorities know that private finance is 'the only game in town', their schemes almost always show that private finance is better VFM than public finance.

The international experience has reflected these realities. While the research literature relating to both developing and developed countries has generally been short on detailed financial evidence, it has shown that while many private road concessions and DBFO projects have been successful, where "success" means commercial viability, a significant number have not. Some have had to be renegotiated on more favourable terms to the private sector or taken over by government when the concessionaires faced inadequate revenues due to users' dislike of tolls and/or higher than expected costs. The broad conclusion is that in order to make such schemes financially viable and attractive to the private sector and users alike, a high degree of political commitment is required. Such political commitment is reflected in various forms of financial support, not all of which are clearly visible to the public, and/or the elimination of competition from roads without charges. (See for example the work of Farrell, 1997; Silva, 2000; Freeman, 2003; Erhardt and Irwin, 2004; Estache and Serebrisky, 2004; Bel and Fageda, 2005; Boardman et al., 2005.) In the context of rail, the capital intensive nature of the industry has meant that it has proved impossible to run a large network on a commercial basis, irrespective of ownership structure, and without subsidy, capital grants, loan guarantees, or debt forgiveness.

This paper focuses on the financial or distributional aspects of projects because the policy choice is mainly between different financing options: public, either via sovereign debt or taxation; or private, using the private sector as a financial intermediary to access commercial - and costlier - debt. Clearly the social and economic benefits of projects will also differ in terms of consumer surplus to the users and environmental benefits/damages, and policy towards PPPs does have an impact on which projects are selected for implementation and how many projects can be funded. The paper is organised in several sections. The next (second) section sets the scene by examining in seven sub-sections case studies of major UK transport PPPs. The third, fourth and fifth sections examine more broadly the underlying issues raised by these cases. Section three examines accounting rules that provide incentives to use private finance whether or not a PPP project is VFM. Section four examines the implications when private finance is the only available means for public authorities to invest. Section five draws together some lessons learned about the use of PPPs. A short final section draws out the implications for the choice of financing method. 


\section{Setting the Scene}

The paper considers the financial costs and rewards to the various stakeholders involved in a wide variety of partnership forms, on-going and completed, successful and otherwise, in rail, road and air traffic services, all sectors that have traditionally used conventional public finance. It uses financial evidence derived from the research literature, official and regulatory reports, statistical sources and the press. The stakeholders will vary according to the type of arrangement (the taxpayers, users, providers of finance, contractors, etc.). Thus financing and funding transport is also about the politics of and accountability for such projects. Our findings, updated as appropriate from previous publications (including Shaoul, 2010; Shaoul et al., 2007a; Shaoul et al., 2008; and Shaoul et al., 2011) provide evidence to substantiate our argument that procuring transport infrastructure and services via PPPs is expensive, far more expensive than public finance, and fraught with risk. The cost is such that the funding that is earmarked to pay for the finance is usually insufficient and additional taxpayer funding to make up the shortfall displaces other services.

\subsection{The National Railways}

Since the privatisation of the national railway industry (the network, locomotives, passenger, freight and engineering services) in the mid-1990s, the railways have been partfunded by a system of operating subsidies to private sector train operating companies (TOCs) which have a franchise to run designated services for a specified period. The train operators use the subsidies to lease the trains from privately owned rolling stock companies and pay track access charges to Network Rail, a private not-for-profit network infrastructure company, as well as to defray their other costs. The cost of leasing the rolling stock, the broad outline of which was set at privatisation, and of accessing the track, whose charges are set by the rail regulator to cover the cost of approved investment, maintenance and renewals, are essentially fixed costs for the franchise operators. While some fares were to be regulated and allowed to rise no more than $1 \%$ above inflation, some fares are unregulated. These two fixed costs, the leasing and track access charges, the expected level of demand, the fare levels and the cost of running train services determine the level of subsidies required.

The stated purpose of breaking up the integrated industry into numerous private companies linked by contracting relationships was to generate the efficiency and dynamism presumed to be lacking in the publicly owned operator, British Rail (BR) (Department of Transport, 1992) and to facilitate capital investment free from Treasury spending limits. Competition for the franchises to run passenger services, if not competition on the tracks, would ensure efficiency and value for money. 
The leasing of rolling stock would enable companies to bid for the franchises and permit new entrants to the market. Together, the new structure would generate competition and efficiency bringing benefits to all.

In terms of PPPs, the railways therefore represent a mix of public and private finance and funding channelled largely through a system of concessions or franchises, whose service levels, frequencies and routes are set out in their contracts (not publicly available) and monitored by regulation, with inadequate performance against targets subject to penalties.

\section{The first round of passenger rail franchises 1995-2004}

The right to operate the train services was divided into 25 franchises for which competitive bids were invited between 1994 and 1997. Franchises were generally awarded to the bidders requiring the lowest level of subsidy, with only one awarded without subsidy. Subsidies were more than double that given to BR in the 1980 s and the early 1990 s before the restructuring of the industry for privatisation. Although the intention was that subsidies would decline to $£ 0.9$ bn by 2003 , that had still not been achieved by 2009 . The 25 franchises were awarded to just 11 companies, a number that has since halved as companies have merged, been taken over or left the industry.

The much vaunted performance targets were no more demanding than those set for BR in the interim regime 1994-96. Thus, no improvement was built into the franchises system, belying the government claim that services would improve. Performance indicators of punctuality and reliability are no longer published in a way that permits direct comparisons with standards of performance prior to privatisation. Performance deteriorated, particularly in the period 2000 to 2005, after Railtrack's failure to maintain the track in a safe condition, and subsequent collapse. Although much improved subsequently, even in 2009 performance has still not attained BR's level. But even these results would not have been achieved if the train operators had not made extensive use of a loophole in the regulations that allows them to exclude from performance data days when they have serious problems and extend the scheduled time. The deterioration in levels of service is widely attributed to the de-manning that took place after privatisation and the lack of capacity on parts of the network due to inadequate investment, leading to overcrowding and delays.

By 2006, the combined revenues (from fares and subsidies) of the 25 passenger franchises had risen from $£ 4.6 \mathrm{bn}$ in 1997 to $£ 6.2 \mathrm{bn}$, more than double BR's total revenues in the last year (1993-94), when BR ran the integrated railway system (Shaoul, 2006). This was the result of several factors: fare increases on some routes that were higher than the rate of inflation; increased passenger numbers alongside a general increase in all modes of travel due to the expanding economy and traffic congestion on the roads; 'revenue protection' measures to ensure that passengers paid for their journeys; and the end of the sale of discounted fares on board the trains. But finally, and most importantly, revenues rose because subsidies were considerably higher than in the 1980 s and early $1990 \mathrm{~s}$. Subsidies to BR averaged $£ 700 \mathrm{~m}$ a year or $20 \%$ total revenue and $£ 1.6 \mathrm{bn}$ or about $17 \%$ income between 1985to 1990 and 1991 and 1994, in the run up to privatisation. Following privatisation, subsidies accounted for $£ 2.1 \mathrm{bn}, 71 \%$ of total income in 1996 , only declining to $£ 1.1 \mathrm{bn}, 17 \%$ in 2006 . 
It should however be noted that it is extraordinarily difficult to get clear and consistent information about the payments of subsidies to the train operators (Shaoul, 2006). All this leaves out the capital grants given to the network operator.

However, the increase in revenues not withstanding, the majority of the franchisees are totally dependent upon subsidies to recover their costs and deliver a profit. Without subsidies, aggregate losses in 2006 would have been $£ 1.1 \mathrm{bn}$, a sum equivalent to their subsidies. Only a handful of the TOCs made a profit. They paid out $£ 144 \mathrm{~m}$ in dividends to their parent companies in 2006 and $£ 1$.5bn since privatisation, due to the extensive system of public subsidies, not superior performance.

Had the 'market' and the franchise agreements operated as intended, many of the TOCs would have gone out of business. While the original franchises were let 'competitively', i.e., to the bidder requiring the lowest level of subsidy, the bids turned out to be hopelessly optimistic on the TOCs' part (Transport Select Committee, 2004). With the government refusing to countenance re-nationalisation in any form, termination of the contracts and bringing passenger services back in house was not normally perceived to be an option. The short lived Strategic Rail Authority (SRA) ${ }^{3}$, was therefore obliged to step in to ensure continuity of train services and amend the franchise agreements.

Firstly, the SRA increased the subsidies (SRA 2003). In one of the more egregious examples, Connex South East received $£ 58 \mathrm{~m}$ in 2002 due to differences in its cost and revenue assumptions. "They had got their numbers wrong," as the SRA chair explained to the Transport Select Committee (Transport Select Committee 2004). In the event, shortly after increasing the subsidy, the SRA terminated the franchise due to the TOC's poor performance. In January 2003, the press reported that more than half the TOCs were receiving emergency bailouts in the preceding two years. Amid claims that the SRA was imposing 'gagging clauses' on the TOCs to prevent them disclosing information about their bailouts, information became publicly available because the Stock Market requires the disclosure of information that affects corporate profitability.

Secondly, the SRA converted some of the franchises into management only contracts with payment on a 'cost plus' basis and a higher subsidy for less risk, prior to re-tendering the franchises. In 2003, "over one third of the franchises" (SRA 2003, p47) were operated in this way, which the SRA admitted "had become expensive" (SRA 2003, p39).

3. Infrastructure access - charges and competition on the tracks (mainly between freight operators) - is regulated by the Office of Rail Regulation (ORR, formerly the Rail Regulator) whereas competition for exclusive passenger concessions is managed by the Department for Transport, by the periodic negotiation and award of Passenger Franchises. For a short period this responsibility was assigned to a Strategic Rail Agency. One of the ORR's duties is to reconcile the government's demands for services from the passenger operators (its high level output statement) with the public funding made available to the railway from the government (statement of funds available). 


\section{The second round of franchises}

While the SRA had renegotiated first round of franchises at the taxpayer's expense, in 2004 it negotiated a second round that were no more successful.

The routes were restructured to make them more commercially viable and the only companies eligible to bid were those in the transport sector, thereby confirming the monopoly position of the existing concessionaires. A few of the lines, such as the East Coast Main Line (ECML), were believed to be sufficiently profitable to enable the franchisees to pay the government an annual premium, and were awarded on that basis. (The ECML is a busy route connecting London with Newcastle upon Tyne, Edinburgh and Aberdeen, as well as a number of other cities). In an effort to ensure the profitability of the franchises and thereby avoid any future contract renegotiation, the government sought to limit the operators' risk by assuming some of its revenue risks, the key risk. New franchises included clauses that would after four years reimburse the operators for $50 \%$ of any shortfall in revenue below $98 \%$ of the original forecast and $80 \%$ of any shortfall in revenue below $96 \%$, and claw back $50 \%$ of any increase in revenue above $102 \%$ of the original forecast (Transport Select Committee, 2006).

In the event, GNER Ltd, which won a second 7 year contract for the ECML franchise in return for a $£ 1.3 \mathrm{bn}$ premium over the life of the contract, handed back the keys in 2006 when the franchise proved to be less profitable than its own overoptimistic forecasts had suggested. Indeed, simple projections of GNER's cash flow, based on its annual report and accounts revealed that it could only have been viable if there had been a most unlikely $10 \%$ growth in passenger revenue. GNER then ran the franchise for a further year on a management only and risk-free basis. Yet its projections had evidently satisfied the Department for Transport's financial advisors, since the then Transport Minister brushed off the industry view at the time that GNER had over bid. He said, "We crawled over the figures over the last few weeks because we wanted to make sure that the bid actually stood up". But within two years, it had collapsed.

In August 2007, the government awarded the ECML franchise to National Express in return for a more onerous $£ 1.4 \mathrm{bn}$ premium over seven years. But National Express was no more successful. After paying the government $£ 85 \mathrm{~m}$ in 2008, in April 2009 National Express demanded a renegotiation of its franchise. Not only did it demand to be let off the remaining charge, it also demanded that it be paid to keep running the railway on a management only, risk free basis. In response, the Department for Transport (DfT) insisted that it cannot renegotiate the contract and threatened to impose a "cross default" clause that would strip National Express of its other two profitable franchises, if it failed to keep up with payments on the ECML. Later, the government terminated the contract to deter other rail operators from seeking to renegotiate their contracts, increase the subsidies or reduce their premia, as passenger numbers, revenues and profits declined due to the global recession that has undermined the optimistic bids underpinning the recent franchise agreements. The government formed a publicly owned company to run the franchise which was originally to be re-let in 2010, although this has now been twice postponed. Its attempt to strip National Express of its other franchises failed largely due to the fact that they were held by legally separate subsidiaries. 


\section{The third round of franchises}

In August 2012, undaunted by the experiences, the government announced that the winning bidder for the West Coast Main Line (WCML) franchise was FirstGroup, displacing Virgin Rail, who had held the franchise for the previous 15 years. The WCML is now the busiest and most profitable route, connecting London with Birmingham, Manchester, Liverpool and Glasgow.

Under the terms of the deal, FirstGroup, whose West Country franchise was one of the worst performers, will pay the government about $£ 10$ bn over 13 years or $£ 13 \mathrm{bn}$ if the franchise is extended to 15 years, with about $90 \%$ payable in the last seven years of the contract. While the newspaper reports have mentioned a lower figure of about $£ 5.5 \mathrm{bn}$, this refers to the net present value (NPV) of the $£ 10 \mathrm{bn}$ payments. According to FirstGroup, the payments will rise from $£ 26 \mathrm{~m}$ in the first full year to $£ 739 \mathrm{~m}$ in the final year ending March 2026 on an NPV basis, or at least $£ 1.5 \mathrm{bn}$ in cash terms. Its main rival, Virgin Rail, had submitted a bid that would have paid $£ 8.6 \mathrm{bn}$ and $£ 11 \mathrm{bn}$ over 13 and 15 years respectively.

These payments assume a compound growth of $10.4 \%$ a year, more than Virgin achieved during the renaissance of rail under an expanding economy that saw an increase in all forms of travel, and two percentage points more than Virgin Rail was forecasting. Of this half will come from an increase in ridership (usually estimated as a multiplier of 1.2 or 1.3 of GDP which is optimistic in Britain's present double dip recession) and half from running new services to the small cities of Shrewsbury and Telford. Seat numbers will rise by $35 \%$ by leasing an additional 106 new coaches and 11 new trains. Whereas previous franchise holders have been bailed out by the government's "revenue support" scheme, this has now been scaled back. The government will only make up to $80 \%$ of the revenue shortfall if there is a difference of $4 \%$ between the official GDP forecasts upon which the estimates are based.

FirstGroup claims that there is room for cost cutting, which means cutting jobs, wages and conditions, and on board services. Most of all it will mean rising fares, in a country that already has high fares per mile. Next January, fares are set to rise by an average of $6.2 \%$, much faster than the average rate of salary increases and with the economy in recession.

Thus the scene is set for another franchise collapse, as all the commentators in the media, including the pro-market business press, but not the government, recognises. But the risk to FirstGroup is small, just $£ 245 \mathrm{~m}$, the amount it will forfeit if it hands back the keys before the hefty payments to the government kick in after 7 years.

To conclude, the passenger rail franchises have proved to be a failure both in terms of performance and cost to users and taxpayers alike, and this is almost universally recognised - apart from the government, its advisors and the train operators, the beneficiaries of the regime. Such outcomes were entirely predictable. The fragmented and private ownership structure imposed on the industry ignores the basic realities of the industry. 
Firstly, the essential problem of the railways the world over is that as a highly capital intensive industry it is difficult if not impossible to recover the full cost of running the industry, including the cost of enhancing the infrastructure and rolling stock, from the fare box, which is why, in the post-war period at least, public ownership and investment were necessary. Privatisation, which increases the claims of finance, only exacerbates the problem. Secondly, in the context of Britain, since the railways already had the lowest subsidies in Europe and the highest labour productivity, it was always going to be difficult to cut costs further to provide the necessary headroom for profits without either affecting service quality and safety or increasing subsidies and/or fares (Shaoul 2004). Taken together, this means that the risks that the government always retains are the demand, default, political and reputational risks and these are the most important ones.

\subsection{A metro system - London Underground}

This section examines these issues of costs and risks in the context of the collapse of the three London Underground PPPs, by far the largest element of Britain's PPP programme. These were expected to procure capital investment worth $£ 30 \mathrm{bn}$ over 30 years for its aging underground network, used by $3 \mathrm{~m}$ people a day for commuting and travelling around central London. Transport for London ( $T f L)$, London Underground's parent body, divided the lines into three separate packages and signed contracts with three consortia in December 2002, which became operational in April 2003. While London Underground would continue to operate passenger services, the consortia would maintain and refurbish London Underground's tracks, signals, stations and rolling stock in return for an annual charge for 30 years, although the contracts would be renegotiated every seven and a half years.

The run up to contract signing in 2002 had seen increasing public hostility to the outcomes of rail privatisation, particularly following the collapse of Railtrack, the private infrastructure operator. The London Underground PPPs were no more popular and were widely viewed as unworkable, even by sources such as the Economist, normally supportive of governments' market based policies. Prior to contract close, there had been several highly critical financial appraisals of the proposals (see Gaffney et al., 2000; Glaister et al., 2000; NAO 2000). They had queried the claims by the government's advisors (PwC 1999; 2000) that the private sector companies would be able to make savings of 30 percent on London Underground's costs. Nevertheless, the government was committed to the policy and the projects and forced the PPPs on an unwilling TfL and pledged taxpayers' money to the projects.

In the event, the PPPs proved so costly that TfL had to scale back the investment. The Department for Transport (DfT) gave TfL about $£ 1$ bn a year, more than five times the existing grant, even though it had earlier stated its intention of terminating all subsidies for London Underground. Despite not being a signatory to the deals, it also guaranteed 95 percent of the contractors' approved debts to reduce their cost of borrowing and reassure their financiers in the wake of Railtrack's collapse, with the result that the lenders "had limited downside risk" (NAO 2004a, para 10b). In addition, the DfT promised TfL that should London Underground find itself in financial difficulties as a result of the PPPs, the Secretary of State for Transport "regards it as untenable that" he would not consider further financial aid or that "he would stand by and do nothing in those circumstances". 
In other words, the government would, in the event that London Underground found itself unable to meet its commitments, provide extra finance. This was tantamount to underwriting the consortia's income.

The NAO carried out two investigations (2004a; 2004b) after financial close that carried significant caveats. In the first, it observed that there was "only limited assurance that the price that would be paid to the private sector was reasonable" (NAO 2004a, para 4). In the second, it noted that while the contracts contained financial bonuses and abatements to incentivise performance, "the effectiveness of incentives is unproven" and these might have only a "limited impact" (NAO 2004b). It questioned whether the oversight mechanisms provided by the contract would be effective and warned that the ability of the PPPs to deliver the necessary improvements would depend upon effective contract management and the willingness of the DfT to provide the necessary financial support after the first 7.5-year phase.

The additional costs of private finance are those costs that would not otherwise have been borne under public procurement. They include the "leakages" resulting from first the higher rate of interest to the banks and second the post-tax profits attributable to the companies and their subcontractors. This may be estimated conservatively, using the data from the accounts and making estimates about the profit margins of their subcontractors ( 5 percent of the subcontracted revenues). With Metronet subcontracting out half of the work and Tube Lines three quarters of the work, largely to their sister companies, the leakages amounted to between 14 and 22 percent of the 3 consortia's annual receipts over the 7.5 years. Alternatively, to put it another way, around 20 percent of London Underground's payments on its three contracts was the result of using the private sector as a financial intermediary. While such estimates are indicative rather than definitive, they are broadly in line with the additional costs noted in our study of hospitals and roads (Edwards et al., 2004).

The government's expectation was that the private sector's superior performance would compensate for this additional cost; this did not turn out to be the case. Despite all the government subventions, within two years the two Metronet companies, which had two of the three 30 year contracts worth $£ 17 \mathrm{bn}$, were behind with their investment programme and over budget. In July 2007, just over four years since the start of the PPPs, they went into administration with debts of at least $£ 2$ bn after the owners, five international corporations, refused to commit further funding to their Metronet subsidiaries. The bankruptcy of the two Metronet consortia was precipitated by the refusal of the Rail Arbiter to award more than a fraction of their appeal for increased payments from London Underground to fund their nearly $£ 1$ bn overspend and a further $£ 1$ billion projected overspend by 2010 . The Rail Arbiter said that if Metronet (referring to the two companies) "had delivered in an efficient and economic way, its costs would have been lower".

The Mayor of London announced that $£ 750 \mathrm{~m}$ would be made available to the Administrator to ensure that the trains would keep running. The two Metronet companies would continue their work while in administration, while their suppliers - their sister companies - and the workforce would continue to be paid. 
Although TfL tried to reconfigure the contracts to sell them back to the private sector, it ended up retaining the ownership of the Metronet companies and the division of labour established by the PPP arrangements. It announced the postponement of some of the improvements expected under the PPP due to the additional costs created by Metronet's inefficiencies and collapse. Thus, the taxpayers and travelling public will bear the cost.

The NAO (2009) attributed the failure of Metronet to its corporate structure, governance and leadership. The five shareholders had to agree many of the decisions unanimously, but with shareholder-dominated supply chains, they had conflicting interests depending on their roles. The top management was therefore in an impossible situation, changed frequently and was unable to manage the work effectively. The NAO said,

"These suppliers had power over some of the scope of work, expected to be paid for extra work undertaken and had better access to cost information than the management. The poor quality of information available to management, particularly on the cost units of the station and track programmes, meant that Metronet was unable to monitor costs and could not obtain adequate evidence to support claims to have performed economically and efficiently." (NAO 2009, para 7).

The DfT had to give grants of $£ 1$.7bn to TfL to help purchase Metronet's debt obligations. The NAO observed that despite underwriting Metronet's debt, the DfT was not party to the contract, was not represented on London Underground or Metronet's board of directors, and was therefore unable to manage its own risk. Ultimately reliant on information from Metronet about performance and costs, it effectively expected Metronet, the shareholders, lenders and everyone else to identify and mitigate its own risk.

The Tube Lines contract was no more successful. In May 2010, when the first 7.5-year phase of the PPP ended, TfL announced that it would take over Tube Lines at a cost of $£ 310 \mathrm{~m}$. This was because Tube Lines was set to get only $£ 4.4 \mathrm{bn}$ for the next 7.5 -year period, $£ 2.8 \mathrm{bn}$ less than it expected or wanted. With Tube Lines' costs rising, and its estimate for the next period beyond London Underground's budget, TfL had referred their bid to the Rail Arbiter. The Rail Arbiter's report showed three different costs: Tube Lines at $£ 7.2 \mathrm{bn}, \mathrm{TfL}$ 's at $£ 4.1 \mathrm{bn}$ and his own at $£ 5.1$ to $5.5 \mathrm{bn}$, which was closer to TfL's cost estimates than Tube Lines. Thus in all three cases, the independent Rail Arbiter found against the three PPP companies in terms of costs and efficiency. Unable to agree significantly better terms with TfL, the shareholders sold up at the breakpoint in the contract with compensation, when the deal became less profitable than they had anticipated.

The London Underground PPPs are important because they refute the assumptions at the heart of the PPP policy: first, that the private sector is more efficient than the public sector; second, that risk (and therefore cost) is transferred to the private sector; and third, that the private sector's greater financial and commercial expertise will ensure viable and sound deals capable of delivering the specified contract performance. 


\subsection{Joint venture - the case of Air Traffic Control}

The case of National Air Traffic Services (NATS), Britain's air traffic control operator and the third largest air traffic controller (ATC) in the European Union, provides another example of a PPP launched ostensibly to provide extensive capital investment, this time in the form of a joint venture between the public and private sectors.

NATS provides take-off and landing services at 14 UK airports, some international services and, most importantly, en route air traffic control services for aircraft flying over the UK and its North East Atlantic airspace. About $80 \%$ of NATS' revenues are derived from North Atlantic travel. Its services are vital if the airlines are to operate safely and efficiently. But with Britain's air lanes severely congested, the overarching safety requirement may lead to delays that create extra costs for its customers, the airlines, without careful management.

The then Conservative government reconstituted NATS as a corporation operating as a subsidiary of the publicly owned Civil Aviation Authority (CAA) and proposed to privatise it, which the opposition Labour party opposed. But as the party in power in 1998, the incoming Labour Government published plans for a partial sale of NATS to a private partner, under its flagship PPP policy, and introduced the necessary enabling legislation in 2000. The stated reason for this PPP was the need for at least $£ 1$ bn of capital investment over a ten year period. No evidence was produced to explain what was required, the validity of the estimates, or why NATS could not continue to borrow from its existing sources. In March 2001, the government agreed to transfer a $51 \%$ stake in NATS to the Airline Group, a consortium of seven airlines, NATS' UK customers, for about $£ 800 \mathrm{~m}$, more than twice the expected sum.

But in May, the Airline Group told the Government that as a result of the decline in the transatlantic traffic and costs that it had overlooked, it could not afford its offer price and a reduction was agreed. In July 2001, the government transferred a controlling stake in NATS to the Airline Group, a consortium of UK airlines, for $£ 750 \mathrm{~m}$, with the expectation that its new owners would invest in new equipment to the tune of $£ 1 \mathrm{bn}$ over 10 years. The Airline Group financed the deal with $£ 55 \mathrm{~m}$ of their own capital as equity and raised the rest as loans that that would be repayable by NATS, with the intention of raising the $£ 1$ bn investment funding via additional loans.

Thus, NATS would be a PPP or joint venture between the private sector and the Civil Aviation Authority, NATS' former public sector parent. But within three months, in the aftermath of the terrorist bombing of the World Trade Centre in September 2001 which halted transatlantic traffic for three days and the subsequent downturn in traffic volume, NATS' bankers became concerned about NATS' ability to service its debts, forcing NATS to ask for government help to stave off bankruptcy. Given the government's international treaty obligations to provide air traffic services and commitment to its flagship policy, it had no option but to provide financial support. 
Although NATS and the government attributed the collapse to unforeseeable events, an analysis carried out before financial close (Shaoul 2003), based upon the widely expected $£ 350 \mathrm{~m}$ purchase price, had shown that the project was unviable: it was never going to be affordable, even without the unprecedented downturn in travel after 9/11. The PPP worsened rather than resolved NATS' financial problems. But no risk assessment was carried out prior to the PPP even though the government remained a part owner and as signatory to international conventions guaranteed service delivery (NAO, 2002b). This was despite the fact that the PPP generated additional risks as a result of the high level of private sector loans.

\subsection{On-going DBFO contracts in Britain}

We examined the first eight of the Highways Agency's 14 contracts $^{4}$ to extend and maintain its roads (Shaoul et al., 2006). These eight contracts, operational since 1997, are paid for by the Highway Agency on the basis of traffic volumes or shadow tolls. The evidence relating to one of these roads, and there is no reason to believe that the results are substantially different for the others, suggests that in engineering terms, the road was constructed in accordance with the contractual requirements and its operation and maintenance are very good, although this assessment is considered in isolation from the cost (Shaoul et al., 2007a). Certainly, the Highways Agency views them as a success, although it has published no financial evidence about the operation of the contracts to demonstrate whether they constitute VFM in practice.

The concessionaires are special purpose vehicles (SPVs) or consortia, typically composed of a financial institution and construction and maintenance companies, which raise debt to finance the projects. As shell companies, the SPVs typically subcontract the work to their sister companies. The Agency pays about $£ 220 \mathrm{~m}$ a year for these eight DBFO contracts, indicating a total cost of about $£ 6 \mathrm{bn}$ over the 30 year life of the contracts. With traffic volumes rising, the SPVs are commercially successful companies. Annual payments in just three years were $£ 618 \mathrm{~m}$, more than the $£ 590 \mathrm{~m}$ cost of construction.

The annual cost of finance, interest payable and post tax profits, was about two thirds of the revenues received from the Highways Agency, although in some years this was even higher due to refinancing gains. It illustrates the importance of capital as opposed to operating costs in roads. We estimated the additional cost of private over public finance to be more than $20 \%$ of revenues a year. This was however a conservative estimate, since the parent companies have additional, undisclosed sources of profit via subcontracting the construction, operation, maintenance, and financing of the projects to related companies, as well as refinancing gains, making it impossible to establish the total cost of using the private sector as financial intermediaries.

4. http://www.highways.gov.uk/aboutus/documents/s110129_Network_Management_JULY.pdf Jean Shaoul, Anne Stafford and Pam Stapleton- Discussion Paper 2012-6 - (C) OECD/ITF, 2012 
The additional cost of private over public finance raises two issues: the cost of risk transfer and affordability. The higher cost of private finance is justified in terms of risk transfer. But since risk and risk transfer are ex ante concepts, it is impossible to quantify the risk ex post facto and thus determine whether or not it constitutes VFM.

In the case of these DBFO roads, the main risks (NAO 1998, Shaoul et al., 2007a) were held by the public sector because all eight projects had already gone through the design and planning approval stages. Other than construction risk, there is therefore little direct risk to the parent companies (whose initial investment was in any event very small) and almost none to the banks, since the state de facto guarantees the debt. Indeed, the credit ratings agency Standard and Poor's, noted that the Highways Agency's "obligations were directly guaranteed by government" $(2003,9)$.

The higher cost of private over public finance also raises questions about the impact of these schemes on the rest of the Agency's budget. According to a Highways Agency official, the commitments for all its DBFO projects are about $£ 300 \mathrm{~m}$ a year, or $20 \%$ of its budget, for 8 per cent of its network (Taylor, 2005). He said that the new contract for the M25 would add a further $£ 300 \mathrm{~m}$ a year, meaning that $40 \%$ of the budget will be committed for a very small proportion of the network. Thus while these roads will be maintained, there may be little money left over for the rest of the network, which may not be the most rational way of prioritising road maintenance.

Moreover, the more recent projects, including the M25 DBFO, have an even higher additional cost of private finance (NAO, 2010). Following the collapse in the subprime mortgage market in 2007, the banking crisis in 2008 and the subsequent credit crunch, bidders for DBFO projects were finding it difficult to raise finance from either the banks or the bond markets. This was despite the nationalisation of some of the banks, huge subventions to the banking sector and an array of other financial measures to increase liquidity and bank lending. Having placed no requirements on the banks to lend and eager to secure the flow of PPP projects, the British government decided to set up its own Infrastructure Finance Unit to lend money on commercial terms to the banks to finance PPP projects, and thus rescue both the policy and the projects in the pipeline. This was justified in terms of the need to "stimulate the economy", although loans to the public authorities would have achieved the same results more cheaply.

The banks in turn lent on at rates that averaged 2.5 to 3.5 percentage points higher than their own borrowing rate, while at the same time negotiating more onerous conditions with the PPP consortia that reduced their risk (NAO 2010). The banks increased the cost of financing PPP projects by between 20 and 33 percent (PAC 2010), claiming that this was a more accurate reflection of their risks. However, as it is the public agencies, based on taxpayers' money, that are ultimately responsible, it is difficult to understand how their risk is anything other than minimal. The NAO estimated that between $£ 500 \mathrm{~m}$ and $£ 1 \mathrm{bn}$ of extra costs were locked into these PPP projects. This is over and above the "normal" additional cost of private finance described earlier. Furthermore, the NAO noted that the procuring authorities had not recalibrated their VFM studies and questioned whether such projects were VFM. 
Several inter-related conclusions flow from this analysis. The cost of the DBFO shadow toll road projects are in line with other UK DBFO road projects (Shaoul et al., 2008a) and hospitals (Shaoul et al., 2008b), and both toll and shadow toll roads in Spain (Acerete et al., 2009). The evidence suggests that the Highways Agency has paid a high price for risk transfer and challenges the notion that risk transfer delivers VFM. It also raises questions about affordability and suggests that these contracts must entail cuts elsewhere. This in turn means that far from providing additionality, the new construction (and maintenance) comes at the expense of other Highways Agency projects.

\subsection{M6 private toll road}

In 1989, the then Conservative government proposed a privately funded and financed venture to build a new road to relieve congestion on the motorways around Birmingham. The concession for the M6 toll road would run for 53 years, expected to be three years construction and 50 years operation. After long planning delays, the road opened at the end of 2003 , with a construction cost of about $£ 700 \mathrm{~m}$. With its charges unregulated, the road operator originally set its prices to minimise its future maintenance costs by effectively pricing heavy goods vehicles off the road.

Shaoul et al., (2008a) found that in 2006, revenues, including those from the service station, were $£ 51 \mathrm{~m}$. This was widely acknowledged to be less than expected due to lower than forecast traffic volumes, although traffic was rising and had reached 50,000 on an average working day (company's website). Intended to relieve congestion, the new toll road still carries only 20 percent of the traffic on the existing motorway, as drivers are reluctant to pay for using the road while others remain free, and despite reducing its charges for heavy goods vehicles from $£ 11$ to $£ 7$. The toll road has thus failed to achieve its stated raison d'etre.

The company was financed by debt, which at $£ 819 \mathrm{~m}$ was considerably more than the construction cost of the road (about $£ 700 \mathrm{~m}$ ). The interest payable to service the debt was $£ 45 \mathrm{~m}$, an effective interest rate of $5 \%$. While this is as yet low and only marginally more than the cost of public debt, it may increase, as typically the interest payments are deliberately set low in the early years when revenues may be low. After paying interest, the company made a post tax loss of $£ 21 \mathrm{~m}$ in 2006 . Losses continued and had risen to $£ 28 \mathrm{~m}$ in 2008.

With construction complete the company refinanced its debt in June 2006, taking on a larger debt that would release about $£ 350 \mathrm{~m}$ cash for investments elsewhere. This serves to increase the concessionaire's risk. It also increases the risk to the Highways Agency which would have to assume responsibility for the road should the concessionaire go under.

Anxious to increase the low traffic volume, the concessionaire came to an agreement with the government to use $£ 110 \mathrm{~m}$ of the proceeds to finance the construction of two new road developments that would feed into the M6 toll road, which would not themselves be tolled. 
Although the Highways Agency refused to release both the strategic case and the contract for the developments under a Freedom of Information request for reasons of commercial confidentiality, it did confirm what was implicit in the announcement: that the project had been agreed without advertisement or competition and that the roads had not yet received planning approval.

Irrespective of the fact that the roads will be built (if they are indeed built) without cost to the taxpayer this means that the roads have jumped the capital prioritisation queue as a result of an unsolicited proposal. That is, instead of the Highways Agency using a share of the refinancing gain for other projects, it approved the construction of new roads that may not have been justified on broader economic grounds in order to make the toll road viable, shielded from public visibility and scrutiny under the rubric of 'commercial sensitivity'.

\subsection{Completed road concessions}

Our analysis (Shaoul et al., 2011) of the first two completed or terminated private contracts, the Dartford Crossings and the Skye Bridge respectively, provide further clarification of these issues. We deal with each in turn.

The Dartford Crossings, widely seen as a successful project, involved a private sector consortium building a new $£ 180 \mathrm{~m}$ bridge for the Department of Transport. The bridge, the Queen Elizabeth II Bridge across the Thames, was designed in the mid-1980s to complement the two Dartford Tunnels and cope with the increase in traffic from the M25 that opened in 1986. The concession involved firstly building, operating and maintaining the bridge, which would be tolled, and secondly transferring the two tunnels and their associated revenues and liabilities to the consortium. The tunnels had cost $£ 13 \mathrm{~m}$ and $£ 45 \mathrm{~m}$ respectively to build, had been run by two local authorities and were already tolled. The first tunnel had been fully paid for, but the more recent tunnel carried a debt of $£ 43.5 \mathrm{~m}$. In other words, the concessionaire would manage and receive revenues for the three crossings while paying for the construction and financing costs of two. The concessionaire was a not for dividend company. The concession was awarded for up to 20 years from 1988 and the bridge became operational in 1991. It would terminate when the tolls had covered the cost of the bridge, including its financing.

With traffic flows that were high and higher than expected, the tolls were relatively low and stable ${ }^{5}$, thereby avoiding political controversy, with the result that the loans were paid off six years ahead of schedule in 2002, incurring unexplained and high penalties of $£ 31 \mathrm{~m}$. Our analysis showed that private finance added $£ 50 \mathrm{~m}$ to the total cost, most of which was the $£ 31 \mathrm{~m}$ early repayment penalty, meaning that toll charges could have been lower than the actual price.

5. In 1991, when the bridge opened, charges for the crossings were $£ 1.40$ for cars and $£ 2.20$ for HGVs each way. They are currently $£ 1.00$ for cars and $£ 2.90$ for HGVs, although under a different regime. 
In short, the Dartford Crossings were successful due to high and much higher than expected traffic flows. The tolls were relatively low and stable. It shows that the key to successful projects (and low tolls) lies in high volumes relative to construction and financing costs. Several other factors were important in the design of the concession. The concessionaire was a not for profit company, so no dividends were payable to the parent companies, thereby reducing the cost of finance and thus the toll charges. The Dartford project also included three crossings. That may be justified from a traffic management and operational perspective, but it reinforces the point that making new road schemes viable may entail bundling new construction work with existing high volume roads. One of the tunnels was essentially 'given' to the company since it had been fully paid for, while the other had $£ 45 \mathrm{~m}$ debt outstanding. Without the tunnels, which carried about half the traffic, the toll charges would have had to be very much higher. Thus even the most 'successful' schemes rely on public support. Moreover, that support may not be widely known to the public at large.

The Skye Bridge project, signed in 1991, on the other hand is held up as an example of failure. It involved the private sector building a short bridge - to be tolled - to the picturesque holiday island of Skye, in the west of Scotland, with a population of just 50,000. The concession would last until either total revenues had reached $£ 23.6 \mathrm{~m}$ discounted at $6 \%$ to 1991 prices or 27 years, whichever was sooner. The total cost of $£ 39 \mathrm{~m}$, including the construction cost of $£ 20 \mathrm{~m}, £ 4 \mathrm{~m}$ for operating costs and $£ 15 \mathrm{~m}$ from the Scottish Office for the approach roads, was more than expected (NAO, 1997). The Skye Bridge opened to traffic in 1995.

The cost of constructing and operating the bridge combined with the low and seasonal traffic volumes determined the toll charge, the concession period, and ultimately the net cost to the public sector, albeit to different public sector entities. The intention was that the concessionaire would recover the full cost via toll charges, which would be the same as the pre-existing ferry charges, which would cease to operate on that route. But since traffic volumes were low, this meant that toll charges were high - the highest in Europe per kilometre of road. The Scottish Office, later known as the Scottish Executive, bowed to regional protests that attracted considerable publicity, and agreed to subsidise the tolls for frequent users as from January 1998 and freeze the tolls to users from January 2000, at its own expense. Later it agreed to pay the VAT charges, necessitated by EU law, to avoid toll increases. Continuing political pressure led the Scottish Executive to terminate the concession in 2004 at a cost of almost $£ 27 \mathrm{~m}$.

Our estimate of the additional cost of private finance was about $£ 18 \mathrm{~m}$. However, this estimate was conservative, since it omits the leakages via subcontracting to sister companies. The Scottish Executive ended up paying $£ 7 \mathrm{~m}$ to subsidise the tolls and cover the VAT and $£ 27 \mathrm{~m}$ to terminate the contract, a total of $£ 34 \mathrm{~m}$. It means that if the bridge had been built with public finance, the toll charges, if there were any, could have been set at half the price. 
The Skye Bridge case demonstrates that in freestanding projects with user charges, there are risks to the public purse. In the case of Skye, public opposition to the tolls was so great that ultimately the public authority had to bear the costs it had sought to transfer to the private sector, which had become much greater as a result of private finance. That is, the move to private finance may create additional risks for the public sector, as the experience of some toll roads in other countries has shown, and these risks are ultimately a political issue. The corollary of this is that the private partners' rewards may not be commensurate with either the risks actually borne or the additional risks created. The government has now acknowledged that schemes such as the Skye Bridge are unlikely to be suitable for private finance in that they transfer demand risk (Treasury, 2003).

It is instructive to recall how the government had sought via the contract to mitigate demand risk for the Skye Bridge Company (SBL). Firstly, the Scottish Office extended the period of the concession to 27 years beyond the intended maximum of 20 years to ensure SBL could recover its costs. Secondly, under a 'safety net' provision, SBL would be able to raise tolls by $30 \%$ above the rate of inflation if toll revenues fell below a sum corresponding to 1990 traffic levels, implying a toll charge higher than ferry fares in 1991. Yet the Scottish Office's stated objective was that charges should be no higher than the ferry charges. The Scottish Office thereby ensured that SBL's revenue risk was low, with the risk falling on the road users. Indeed, the NAO admitted as much, reporting that both the Scottish Office and the company believed that the concession was likely to end within 14 to 17 years. More importantly, these revenue protection measures constituted a form of guarantee by the government, despite its original objective of no disguised government guarantees (Department of Transport, 1989) that served to reduce the concessionaire's financing costs (NAO, 1997).

But the higher cost of private over public finance meant that both Skye and Dartford charged tolls which were higher than they would otherwise have been if financed with public debt. With toll schemes it is the road users not the taxpayers who pay. But private finance for public goods with wider external benefits and problems creates an additional cost. In the case of the Skye Bridge, those costs were so high (relative to revenue) that the state had to step in with taxpayers' money: $£ 34 \mathrm{~m}$ for subsidies, VAT and the termination fee, costs that the road users would otherwise have borne. This was higher than the construction cost of the bridge which the then government had said it could not afford. Thus, where traffic flows are low relative to the construction cost, the users - and/or the company - are unable to bear the cost and the costs ultimately fall back on the taxpayer, as the international experience in Spain and Mexico also demonstrates (Acerete et al., 2009).

\subsection{Proposed new bridge: The New Mersey Gateway}

The proposal to build a new bridge, the New Mersey Gateway, in addition to the preexisting Runcorn Bridge, provides an interesting example of the way that the decision to use private finance changes existing arrangements in order to make a new project viable. The $£ 589 \mathrm{~m}$ new bridge is to be built, financed and operated by the private sector and subject to toll charges. 
In an attempt to ensure that traffic flows are high enough to deliver the requisite income and toll charges low enough not to arouse public anger, the concession involves reducing the number of lanes open to traffic on the existing bridge, diverting traffic away from the old bridge towards the new bridge and tolling the existing bridge. This will be the first known instance in the UK of tolling a hitherto free bridge in order to make a private scheme viable.

Having examined the details of these seven UK cases, the next three sections of the paper turn to consider the underlying issues more broadly. 


\section{FINANCIAL REPORTING AND NATIONAL ACCOUNTING}

The rationale for PPPs has changed so much over time that even its proponents have described it as 'an ideological morass' (IPPR 2001). Although the UK government's focus has been on the VFM benefits of PPPs, it was originally justified as a way of providing infrastructure the state could not otherwise afford, and this latter justification is still evident in other countries. But given the high cost of using private finance, it is strange that such a justification persists. The answer to this conundrum lies not so much in terms of the cash governments are able to afford, but in the loans and expenditures that they report and which are therefore visible, or invisible, under some rather complex accounting rules. Two different kinds of accounting are applicable.

Firstly, there is the financial reporting of public entities, which in a small number of countries is also consolidated to form Whole of Government Accounts (WGA). The UK public sector is unusual in that for these purposes it reports using private sector accounting standards. In the early days of PPPs standards were issued locally but more recently the UK has moved to adopt international standards issued by the International Accounting Standards Board (IASB). HM Treasury's initial position was that PPP primarily represents the procurement of infrastructure-based services, implying that the infrastructure asset and related liability would not be recorded in the public accounts. Initially therefore, PPP projects were often off public sector balance sheet, that is, the debt was invisible - an attractive outcome for government. However, broadly speaking this accounting treatment is at odds with requirements from both the UK and international private sector regulators because they view the legally binding future commitments to make annual payments as real long term liabilities. So over time UK PPP projects are tending to move on public sector balance sheet. The on balance sheet treatment is especially true of transport schemes using figures from October 2007, Heald and Georgiou (2011) calculate that $88 \%$ by capital value (although $41 \%$ by number) of transport schemes were on balance sheet.

But it remains difficult to find sufficient information about PPPs to hold government to account. To improve the transparency of financial reporting we (Shaoul et al., 2008) make the following recommendations about the quality and specifically the disaggregation of public sector annual reporting:

Disaggregated information about individual large-scale PPPs should be reported in the financial statements to provide information about the current year's payments, expected payments and future commitments; 
There should be a breakdown in the financial statements of the unitary charge between availability and service elements, and amounts deducted for poor performance;

- An explanation of the risk assessment leading to any off-balance sheet treatment for PPPs should be disclosed,

- Information on all contingent liabilities together with assessments about the probability of crystallisation should be reported by the public authorities and collated and published by the Treasury, in accordance with the recommendations from the EU and OECD that quantitative information about contingent liabilities should be disclosed (EMU, 2003; OECD, 2001).

Contingent liability reporting in relation to PPPs in public sector accounts is especially limited, probably because governments tend to judge the likelihood of a guarantee being triggered as lower than it is. To avoid this Irwin (2007) suggests that public authorities should list all those events that could trigger a guarantee, and evaluate the maximum loss to the government and the expected loss, based on probabilities of listed events. Furthermore, because recession can trigger a number of guarantees in an economy simultaneously just as tax revenues are small, he argues that governments should insist on contributions to a special fund for the estimated cost of any guarantee.

Most other countries that adopt international standards follow those of the International Public Sector Accounting Standards Board (IPSASB), which has been slower to consider the reporting of PPPs. However, these countries will soon find similar pressures as those faced by the UK to bring PPPS on balance sheet as new IPSASB regulations effective from January 2014 essentially mirror those of the IASB.

The second form of accounting is the national accounts (NA) - the macro-economic accounts. In common with other European Union countries, the UK's Office for National Statistics (ONS) prepares these based upon the European System of Accounts (ESA). With respect to PPPs there are two key differences between the WGA and NA: the approaches to the definition of assets and debt. Speaking in broad terms, the WGA show more PPP assets and related liabilities on balance sheet than are captured by the NA within the calculation of the Public Sector Net Debt. Eurostat, the EU statistical office, has provided guidance for reporting PPP assets and related liabilities in the ESA (ESA 95). These regulations determine not only the financial reporting by the relevant entities, but also government statistics relating to debt, capital and current expenditure. Although Eurostat appears to bring PPP assets and related liabilities on balance sheet, there is enough ambiguity in the regulations to mean that this can be circumvented, thereby evading the constraints on public debt imposed by the Stability and Growth Pact. Under Eurostat's ruling, unless the private partner bears the construction risk and either the availability or demand risk, then the asset will count as a public sector asset. While this was widely viewed as a measure to rein in offbalance sheet projects, in practice PwC (2005:61) argue that the EU rules regarding the accounting treatment of PPPs in national accounts are less restrictive than many governments and industry commentators previously feared'. Hall (2005) argues that this is intentional because in principle the EU authorities are in favour of PPPs and see them as a route to enable investment by governments constrained by the EU's own fiscal rules. 
Thus, whereas traditional procurement of infrastructure is usually financed by government borrowing which is visible on the balance sheet of the public sector, and therefore counts towards external or self-imposed restrictions on borrowing, as a UK parliamentary report ( $\mathrm{H}$ of $\mathrm{C}, 2011$ ) has recently acknowledged, there are incentives to use private finance over other procurement options because the rules still exclude PFI from statistical calculations of Public Sector Net Debt. That is, the use of private finance may be attractive to governments, irrespective of the associated interest costs or whether or not the project is VFM, because depending on the relevant accounting regulations the debt may be invisible. Furthermore, as this report explains from a budgetary perspective PFI appears more affordable if one looks into the future for a limited number of years (for example, over a spending review period) even if the total long term cost is higher than traditional procurement.

To counter the tendency of governments to minimise current expenditure and current liabilities by keeping costs out of current budgets and off current Balance Sheets, the report argues that HM Treasury should align the treatment of PFIs in departmental budgets with their (on balance sheet) treatment in financial accounts so that the PFIs score within budgets in the same way as direct expenditure. That is, all future PFI liabilities should count towards assessments of whether the government has met its fiscal rules.

This call for the clear reporting of debt in government accounts aligns with the call by IFAC (2012) for governments to adopt IPSASB regulations so that there can be a better and more transparent reporting of government debt on an international basis. This is because it is a well- established principle that citizens should be able to understand how society's resources are being used. While many citizens may not be capable of interpreting complex financial statements, these are nevertheless a key source of information for informed citizens to hold government to account. In this respect, transparency of financial reporting of PPPs is so essential that Boardman and Vining (2010a) caution that governments should not deal with companies that will not accept the need for transparency.

We (Shaoul et al., 2008) also recommend that public sector external auditors should investigate through the extended supply chain, and determine if private partners are viable and specifically that adequate provisions exist for future maintenance costs on PPP projects. They should ensure that public sector procurers enforce the provisions in contracts to ring fence front loaded payments. Governments should designate private companies that deliver public services as public authorities for the purpose of allowing citizens to make freedom of information type requests. (Under the Freedom of Information Act 2000 the Lord Chancellor has the power to do so in the UK but has thus far chosen not to exercise this power).

Further, to ensure that governments can be held to account for decisions made, we recommend that:

- There should be an agreed limit on the time period when commercial confidentiality may be used as a rationale for non-disclosure; 
- After this time period public authorities should routinely publish their full business cases (In Australia, Victoria regularly publishes business cases online, although financial information may be redacted); and

- Public authorities should conduct post implementation reviews for all major PPP projects and publish them in an agreed timeframe (Shaoul et al., 2008).

Without implementing such recommendations, public authorities cannot provide the public with the information needed about the costs, VFM and affordability, or the sustainability of public expenditure, public debt and the government's implicit liabilities. As Irwin (2007) notes, irritating as it may be for government the possibility of external criticism probably improves decisions.

The absence of appropriate accounting and budgeting rules can lead governments to favour PPP over public procurement. To ensure that their chosen route is adopted, many have withdrawn all other possibilities for public authorities to invest. The outcome is that the favoured approach becomes the only option - 'the only game in town'. In the next section we examine the consequences. 


\section{THE ONLY GAME IN TOWN}

As the OECD (2011) has noted public procurement contracts and concessions work best where there is competition and less well where there is bilateral negotiation with an incumbent supplier rather than open competition. But forcing public entities to use PPPs removes the possibility of competition between traditional procurement and private sourcing. Internationally, this lack of public / private competition has been exacerbated by a shortage of private sector bidders for PPPs. Low numbers of bidders has been attributed to the high bidding costs, but may also be due to barriers to entry (Demirag et al., 2010). Smaller contractors suffer from lack of credibility and contacts in the market place, their balance sheets cannot support the equity investment that senior debt lenders expect from contractors because this increases the contractors stake in the project, and they are perceived to be more at risk of bankruptcy in the economic recession. All of this excludes them from joining syndicates (Demirag et al., 2010). The lack of competition may be aggravated after the preferred bidder stage when significant changes to contracts occur in the absence of competitive forces.

In circumstances of restricted competition where both public and private partners are aware that PPP is the 'only game in town', not only do the private bidders become very powerful, but also there is an incentive to bias estimates in the PSC to ensure that the PPP bid passes the VFM test. Just a few examples illustrate how this can occur. Firstly, the choice of discount factor is critical to the outcome of net present value / cost calculations. Boardman and Vining (2012) show how inflated discount rates increase the desirability of PPP options. Secondly, as it is known that the PSC project is not going to obtain approval there is less incentive to spend the necessary resource for its preparation, and it may not be kept up to date for negotiated changes (Shaoul et al., 2004).

Thirdly, there may be assumptions in the PSC that vary from the private bids. We (Edwards and Shaoul, 2003b) have shown how the same parcel of land to be sold for redevelopment was valued at different amounts in the PSC and private bids. Whereas the PSC based the value of land on the assumption that the public authority would comply with local authority guidance on housing density and $25 \%$ social housing, one private bid ignored both guidelines and so was able to increase the apparent attractiveness of its bid by giving the land a higher valuation. In the context of a tiny difference between the PSC and the private bid this distinction was significant. 
Similarly, Boardman and Vining (2010b) discuss a Canadian example where high negative externalities in the form of disruption to downtown traders located on the path of the Canada Line project were not reflected in the comparison with the PSC, although these externalities would have been less under the PSC project, because it assumed more tunnelling. In the event these omitted costs became real costs when the traders successfully sued for damages.

These examples together with the evidence from failed projects both in the UK and elsewhere raise questions about the public authorities' appraisals of PPP bids. Under circumstances where the government is actively promoting the involvement of the private sector in running public services via PPPs by refusing to make funding available for traditional procurement, policy promotion may come into conflict with rigorous project appraisal. To avoid this Boardman and Vining (2012) suggest that separate government agencies approve projects from those that evaluate them. However, these examples also raise questions about the role of the public authorities' advisors. Advisors have played a key role in devising the policy, the VFM methodology, the implementation process and promoting the policy internationally, but they also have a commercial interest in the policy as an important new market, acting as advisors to both the public and private sectors and in some contracts as partners or major subcontractors in their own right (Shaoul et al., 2007b). 


\section{LESSONS FROM PPPS}

In this section we examine some of the claimed benefits of PPP and consider what experience to date shows.

\subsection{Wide-Ranging Programme Goals and the Nature of Projects}

PPPs often have programme goals that are much more wide-ranging than simply building infrastructure and delivering the associated services, although whether such goals are ultimately achieved may not be formally evaluated. The first UK DBFO roads provide a good example. They were conceived as part of a wider policy of introducing road pricing, and the objectives included testing the enthusiasm of the market for DBFO roads contracts across a range of different roads projects, creating a market for roads and a private road operating industry (NAO, 1998). However, the Highways Agency has not made public any evaluation of whether these objectives, which may have distorted the allocation of winning bids because the projects were deliberately dispersed across a range of companies, were successfully achieved.

The nature of transport assets is that these are large, complex and risky projects, where the public benefits of transport links exceed the benefits accruing to users and investors. They do not benefit from well-functioning private sector markets so they need government support, and despite the rhetoric PPPs remain government projects (Boardman and Vining, 2012).

It is interesting that proponents of PPPs have focused attention on the supposedly favourable comparison between PPP projects that are said to come in on time and to budget against the propensity of traditionally procured assets to overrun time and budget estimates. PPPs, it is argued, provide certainty, although this was not part of the original policy objectives. However, the evidence is mixed. The UK's NAO (2009) reviewed a sample of PFIs and found that $31 \%$ were late and $35 \%$ over budget, so that good performance on these targets is not universal. And of course delivery on time and to budget, which could be achieved by suitable incentive mechanisms in traditional contracts, is no guarantee that the project delivers VFM.

Many PPPs are long term commitments, both because of the need to repay the debt where private finance is involved, and because of the nature of the assets which typically have long expected lives. Very long asset life spans demand predictability and long-term commitments in relationships whilst preserving some flexibility to deal with changing external circumstances (OECD, 2011). 
Thus PPP contracts for infrastructure and related services must hold good for 30 years or be sufficiently flexible to adapt to changing needs easily.

However, flexibility in contracts tends to add cost, potentially making the contract unaffordable. Thus there is a trade-off between flexibility and affordability. Experience suggests that PPPs, particularly of the contractual PFI nature, do not work well in complex fast changing environments where flexibility is needed to respond to changes in: service delivery methods; fluctuating demand driven by changing demographics; and fast moving innovative technological developments. For example, HM Treasury accepts that IT projects are not suitable for PFI (HM Treasury, 2003). Where private finance is involved it makes changes to contracts more bureaucratic and expensive as variations require multi-party consent, including consent from senior debt holders (Demirag et al.,2010).

Proponents of PPPs argue that because infrastructure and services are combined in a single project the private sector has an incentive to minimise whole life costs and that this will lead to innovative design. But across a number of sectors the evidence about innovation is mixed. In transport the lack of innovation may be tied up with the risk associated with planning permission. To obtain planning permission detailed design information must be submitted and approved. This essentially means that innovative design must be known and included in the project before planning permission is granted. But because the private sector typically does not wish to hold planning risk where the project may be controversial, as is often the case, for example, with new roads, the opportunity for innovative design may have come and gone before the private partner has even been appointed (Shaoul et al., 2004).

\subsection{Risk Averse Investors}

Even after the credit crunch, when the proportion of equity has tended to rise slightly, PPPs are typically financed substantially by senior debt, a generally risk averse form of investment. Furthermore, because of this highly geared finance structure the SPV has limited risk carrying capacity (Demirag et al., forthcoming). That is, even the equity investors are risk averse. Risk diffusion away from the SPV is essential to obtain an investment grade rating for the project. Significant financial and performance supports are put in place to limit the liability of the financiers whose primary concern is to ensure that PPP risks do not rest with the equity partners but are passed to the contracting companies. But since the contracting companies do not have the expertise to manage all these risks they hedge or insure unwanted risks. These arrangements are complex so that they require the input of financial, legal and insurance experts. The consequent additional cost to the project is ultimately borne by the public sector procurer (Demirag et al., forthcoming).

HM Treasury (2003) has argued that the independent due diligence tests performed by these risk averse banks will ensure a robust project specification and hence reduce risk for the tax payer, as well as the bankers. But an examination of the capital values of the most well known UK failures, outlined below, confirms Demirag et al's (2010) argument that the financiers' due diligence is only intended to protect their own interests and will not necessarily protect the public interest. 
The $£ 4$.2bn Channel Tunnel Rail Link PPP had to be renegotiated within months of signing. As described earlier, the $£ 800 \mathrm{~m}$ National Air Traffic Services PPP collapsed and had to be rescued by the government within three months of financial close for reasons that were entirely foreseeable (Shaoul, 2003).

The Skye Bridge project was terminated due to public outrage over user charges that were the highest per kilometre in Europe. The cost of termination plus the subsidies to users was far higher than the original construction cost that the public authority had said it could not afford (Shaoul et al., 2011). By far the largest collapse has been that of the three London Underground PPPs, discussed earlier. Two of the concessionaires, Metronet BCV and Metronet SSL, went into administration in 2007 after making substantial losses, while TfL terminated the contract with the third, Tube Lines, in May 2010 at the breakpoint in the contract, after failing to come to an agreement on costs.

Taken together, it means that a significant proportion of UK transport PPPs by capital value have collapsed, been terminated or only survived because the contracts were renegotiated, penalties waived, etc. The capital value of just the failed/renegotiated transport projects listed above (excluding the failed and renegotiated rail franchises) comes to more than $£ 35 \mathrm{bn}$. This compares with a recent Treasury list of existing projects (that excludes both these and the rail franchises), of $£ 56 \mathrm{bn}$ (Treasury, 2010) and is more than one third of the value of all the $£ 91 \mathrm{bn}$ projects. Such a high failure rate is hardly a ringing endorsement of the banks and financial advisors' ability to ensure a robust project specification and implementation.

However, there is a further point. While the failure of a large or high profile project is reported in the national press, the failure of smaller projects and their consequences may go unreported or reported only locally. There is no register of what happened to projects nor any overall assessment of what happened when projects collapsed, who bore the costs and how this corresponded with the risk premium. Thus, the true extent of project failure is unknown.

In practice the corporate structure of the SPV and its related companies, the legal arrangements around the loan agreements, and performance supports means that each project is ring-fenced so that in the event of failure the private sector partners can walk away, losing only their initial stake in this one project and any penalty as stipulated in the contract. The PFI structure insulates debt investors from holding risk (Keating, 2004)

\subsection{Risk Transfer, Risk Premiums and Evidence of Risk Transfer}

Risk transfer lies at the heart of the rationale for PPP and the UK government claims that the higher costs of private finance are offset by the benefits of risk transfer, although Pollock and Price (2004) suggest that this claim is largely unsubstantiated.

Despite the centrality of risk transfer to the case for private finance the UK government or its agencies, such as the NAO, have not made a comprehensive assessment of the degree to which risk transfer has occurred in practice or has been commensurate with the risk premium or cost. 
For example Pollock and Price (2008) found that while the NAO had made 10 financial studies of operational PFI projects where there had been significant post-contract changes, it only examined the relationship between the risk premium and risk transfer in three of them. What is most significant is that the relationship between risk transferred to the private sector and the risk premium charged for that transfer is obscured by the complex structure of PFI projects (Pollock and Price, 2004).

It has become an oft repeated mantra that risk should be held by the party best able to manage it at least cost, but the allocation of risks between partners has not necessarily been optimal in practice (Quiggin, 2005), and risk premiums may be high because the way that risk profiles change over the duration of PFI projects is not well known ( $\mathrm{Ng}$ and Loosemore, 2007). Irwin (2007) takes a more sophisticated view of risk allocation. He argues that risks should always be allocated along with rights to make related decisions, and that consideration should be given to which party can best exercise real options, such as deferring, expanding, contracting or abandoning the project, and absorb risk. Furthermore, in relation to demand risk, one of the key risks and one that the private sector is usually unwilling to carry, he argues that it should be allocated to the party best able to forecast demand.

Concerns have been raised that the accounting tail may have been wagging the PPP dog, as inappropriate risks may have been transferred to ensure an off balance sheet accounting treatment and/ or that the private bid is VFM compared to the PSC. But what constitutes an inappropriate risk is debatable. Especially the question of who should hold demand risk is unclear. In evidence to the House of Commons ( $H$ of C, 2011) Balfour Beatty a major contractor argued that risks should not be transferred unless the private sector could manage them better than the public sector. While this contractor's list of such risks included demand risks, the House of Commons committee suggested that PFI is only suitable if the risks associated with future demand and usage of the asset can be efficiently transferred to the private sector. Yet, this position contrasts with that stated by HM Treasury (2003).

Evidence about risk transfer in practice is mixed. There are examples where construction risk especially has passed to the private sector, but also cases, as outlined above, where risk has reverted to the public sector. Low penalties for poor service provision suggest, as the NAO (2007a) acknowledged, that the service element of PPP contracts carries little risk for the SPVs. The credit ratings agency Standard and Poor's (2003) confirmed this general point, observing that there been few deductions on PFI/PPP contracts and these had been small, in part at least because the complexity of the contracts made them difficult in practice to enforce. Although projects may fail to transfer risk in the way that the public agency anticipated, the possibility of enforcing the arrangements and/or dissolving the partnership is in practice severely circumscribed for both legal and operational reasons, with the result that a public agency may be locked into a partnership for better for worse (Edwards and Shaoul, 2003a). 
While research and practical experience may be used to resolve issues about the allocation, measurement and pricing of risk, these technicalities are missing the point. PPP is not so much about risk and VFM as it is about creating investment opportunities for the private sector and prioritising the risk-return criteria of private finance over the needs of the public sector (Asenova and Beck, 2010). Our evidence has shown that the public sector has paid dearly for risk transfer, something that the IMF warned governments against:

"It is also possible that the government overprices risk and overcompensates the private sector for taking it on, which would raise the cost of PPPs relative to direct public investment." (IMF 2004, 14). 


\section{CONCLUSION}

This paper has sought to review the experience of the UK's transport PPPs and the financial costs of different types of PPPs to inform the international policy debate about the value or otherwise of using PPPs to secure and manage transport infrastructure.

Firstly, it is clear that the rail projects have failed to deliver the physical outputs expected of them, despite receiving higher funding than was ever available under public ownership. In relation to road projects, there is no evidence to suggest that they are any better or worse than their conventionally procured counterparts. In so far as the DBFO roads are better maintained, and this remains to be demonstrated, then this comes at a high cost and at the expense of other roads.

Some may argue that well written or at least better contracts would have avoided many of the problems outlined above. The argument here is not that the public sector always does things efficiently or that the problems are the result of poor contracts, although some may be. Instead, the point is - and this is our second conclusion - that using the private sector as a financial intermediary adds cost, complexity, bureaucracy - the latter is ironic in the context of the claims made for the policy - and risk in ways that contracts and their implementation in practice, particularly given the paucity of the public sector's resources, cannot overcome.

Thirdly, our evidence has demonstrated that partnerships have entailed a higher cost of finance than conventional public procurement. This is a universal phenomenon and independent of partnership form, contractual or joint venture. Likewise, success, as reflected in commercial viability, is also independent of partnership form.

The higher cost of finance has several inter-related consequences. It is justified, ex ante, in terms of risk transfer to the private sector. It is however very difficult to assess, post-implementation, whether that risk was priced correctly and therefore the project constituted VFM. If the project is successful, then the public agency pays considerably more than under conventional procurement. If on the other hand it is unsuccessful then the risks and costs may be dispersed as the rail franchises, London Underground and NATS PPPS demonstrate. In effect, the risk transfer is not from the state to the private sector, but from the consortia to its subcontractors and their workforce and to the public as tax payers and users, a travesty of risk transfer. The beneficiaries are the banks and to a lesser extent the consortia and parent companies, who are shielded from public scrutiny. These distributional effects confirm the experience elsewhere and in other sectors such as IT (Edwards and Shaoul, 2003a). 
Although a project may fail to transfer risk and deliver VFM in the way that the public agency anticipated, the possibility of enforcing the arrangements and/or dissolving the partnership is in practice severely circumscribed for legal, operational and political reasons, with the result that the public authority may find itself locked into a partnership. The de facto lack of sanctions strengthens the contractor's already powerful financial and monopolistic position, forcing the public authority to (re)negotiate on the contractor's terms.

At best, partnerships have turned out to be very expensive with the inevitable consequences for future service provision, taxes and user charges, not just today but for a long time to come. These projects may burden government with hidden subsidies, diversion of income streams and revenue guarantees whose impact on public finance may not become apparent for many years and may all be triggered at the same time, precipitating a major fiscal crisis.

Fourthly, our financial analysis provides the detailed evidence to support and explain the international experience outlined in general terms in the literature. The high capital cost of transport projects makes it difficult if not impossible for such projects to be financially viable and thus attractive to the private sector. In other words, it is an international phenomenon, not just a British one. This is why governments must ensure some combination of capital grants, subsidies, implicit or explicit underwriting of the private sector's debt or the public authority's payments, bundling together of projects to increase their size relative to transaction costs, project and service downsizing, higher charges for the public authority or the users and a reduction in workers' jobs, wages and conditions.

Why, then are governments internationally still attracted to PPP? One contention is that the use of PPPs enables them to push costs to the future - the rent the money argument Boardman and Vining, 2010b). But renting the money in this way is very expensive, and not a rational choice where there are viable alternatives. As the financial crisis has shown, governments have been able to find substantial sums to bail out their banking systems, often at short notice, so that it was a false argument to suggest there was no money for investment. Perhaps PPP is part of a very different agenda. The Partnerships policy provides a means of opening up to the private sector those parts of the public sector that could not be privatised as viable standalone commercial entities for financial or political reasons.

While the case for PFI/PPP made by successive UK Governments rests upon efficiency and risk transfer from which all would benefit, the real effect has been the redistribution of wealth to the financial and corporate sectors. Under conditions where government has chosen not to make public finance available, focusing on a concept as ambiguous as VFM has made the distribution issue invisible. The so-called VFM case is little more than a rationalisation for a decision already taken.

The implications of these findings are that policy makers committed to the broader public interest should examine the independent evidence and return to the public financing of public infrastructure. 


\section{REFERENCES}

Acerete, B., Shaoul, J. and Stafford, A. (2009) "Taking its toll: the private financing of roads in Spain", Public Money and Management, Vol. 29, No. 1, pp19-26.

Asenova, D. and Beck, M. (2010). Crucial silences: When accountability met PFI and finance capital, Critical Perspectives on Accounting, 21(1), 1-13.

Bel, G. and Fageda, X. (2005) "Is a mixed funding model for the highway network sustainable over time? The Spanish case" in Ragazzi, G., and Rothgatter, W., (eds.), Procurement and Financing Motorways in Europe, Research in Transportation Economics Vol. 15, Elsevier, The Netherlands.

Boardman, A.E., Poschmann, F. and Vining, A. (2005) "North American infrastructure P3s: examples and lessons learned", in Hodge, G., and Greve, C., (eds) The challenge of public-private partnerships: learning from international experience, Edward Elgar Publishing, Cheltenham, UK.

Boardman, A.E., and Vining, A. (2010a), "Assessing the economic worth of public-private partnerships" in Hodge, G. A., Greve, C. and Boardman, A. E. (eds) International Handbook on public-private partnerships, Edward Elgar Publishing, Cheltenham, UK.

Boardman, A.E., and Vining, A. (2010b) 'P3s in North America: renting the money (in Canada), selling the roads (in the USA)', in Hodge, G. A., Greve, C. and Boardman, A. E. (eds) International Handbook on public-private partnerships, Edward Elgar Publishing, Cheltenham, UK.

Boardman, A.E., and Vining, A. (2012), "The political economy of public-private partnerships and analysis of their social value", Annals of public and cooperative economics, 83:2, pp 117-141.

Demirag, I., Khadaroo, I., Stapleton, P. and Stevenson, C. (2010) 'Public Private Partnership financiers' perceptions of risks', Institute of Chartered Accountants of Scotland: Edinburgh.

Demirag, I., Khadaroo, I., Stapleton, P. and Stevenson, C. (forthcoming) 'The diffusion of risks in PPP contracts' Accounting, Auditing and Accountability Journal.

Department for Transport (2004) "The Future of Rail", White Paper, CM 6233, The Stationery Office, London.

Department of Transport (1989), "New roads by new means: bringing in private finance", consultation paper, Department of Transport, CM 698, HMSO, London.

Department of Transport (1992) "The Franchising of Passenger Rail Services", consultation paper, Department of Transport, London.

Jean Shaoul, Anne Stafford and Pam Stapleton-Discussion Paper 2012-6 - (c) OECD/ITF, 2012 
DLA Piper (2006), European PPP Report 2005, DLA Piper, London.

Edwards, P., and Shaoul, J. (2003a) "Partnerships: For Better for Worse?" Accounting, Auditing and Accountability Journal, Vol. 16, No. 3, pp397-421.

Edwards, P. and Shaoul, J. (2003b) "Controlling the PFI process in schools: a case study of the Pimlico project," Policy and Politics, Vol. 31, No. 3 pp 371-385.

Edwards, P., Shaoul, J., Stafford, A., and Arblaster, L. (2004) Evaluating The Operation Of PFI In Roads And Hospitals, Association of Chartered Certified Accountants, Research Report No. 84, London.

Ehrhardt, D. and Irwin, T. (2004) "Avoiding customer and taxpayer bailouts in private infrastructure projects: public policy towards leverage, risk allocation and bankruptcy", World Bank Policy Research Working Paper 3274, The World Bank, Infrastructure Economics and Finance, Washington, DC.

Estache, A., and Serebrisky, T. (2004) "Where do we stand on transport infrastructure deregulation and public private partnership?" World Bank Policy Research Working Paper 3274, The World Bank, Washington, DC.

European Monetary Union (2003) The economics of PPPs. European Union, Brussels.

Eurostat (1995) European System of Accounting ESA 1995, European Union, Brussels.

Eurostat (2004), New decision of Eurostat on deficit and debt Treatment of public-private partnerships, Stat/04/18, 11/02/2004 accessed 21st

November 2005. http://europa.eu.int/rapid/pressReleases

Farrell, S. (1997) "Financing European transport infrastructure: policies and practice in Western Europe", Macmillan, Basingstoke.

Freeman, P. (2004) "Evaluating Project Performance in Transport Projects in Developing Countries", presentation to Transport Research Congress, Istanbul, July, Operations Evaluation Department, World Bank, Washington, DC.

Gaffney, D., Shaoul, J., and Pollock, A. (2000) "Funding London Underground: Financial Myths and Economic Realities", Report published by Listen to London, London.

Greenaway, J., Salter, B., and Hart, S. (2004), The Evolution of a Meta-Policy: the case of the Private Finance Initiative and the health sector, British Journal of Politics and International Relations, 6(4): 507-526.

Glaister, S., Scanlon, R., and Travers T. (2000) "Public Private Partnerships and Investment in Transport", Report for the IPPR Commission on Public-Private Partnerships, London.

Hall, D (2005), 'PPPs: a critique of the Green Paper', Public Services International Research Unit, www.psiru.org - accessed 21st November 2005. 
Hall, D., and Lobina, E. (2005) The relative efficiency of public and private sector water, Report, Public Services International research Unit, University of Greenwich, UK. http://www.psiru.org/reports/2005-10-W-effic.doc

Heald, D. and Georgiou, G. (2011) "The substance of accounting for public-private partnerships", Financial Accountability and Management, Vol. 27 (2) pp217 - 247.

Irwin, T.C. (2007) Government Guarantees: allocating and valuing risk in privately financed infrastructure projects, The World Bank, Washington.

House of Commons (2011), Treasury $17^{\text {th }}$ Report Private Finance Initiative - July 2011, $\begin{array}{lllll}\text { accessed } & \text { on } & 22^{\text {nd }} & \text { August } & 2012\end{array}$ http://www.publications.parliament.uk/pa/cm201012/cmselect/cmtreasy/1146/114602

International Federation of Accountants (2012), "Public Sector Financial Management Transparency and accountability: the use of international public sector accounting standards" accessed on $29^{\text {th }}$ August 2012 at

http://www.ifac.org/sites/default/files/publications/files/Policy\%20Position\%20Paper\%204\% 20For\%20Issue.pdf)

International Monetary Fund (2004) Public-Private Partnerships, IMF, Washington, http://www.imf.org/external/np/fad/2004/pifp/eng/031204.htm

Keating, S (2004), 'Public-Private brinkmanship', Project Finance, Sept 2004, pp 27-29.

National Audit Office (1997), The Skye Bridge, Report of Comptroller and Auditor General, HC 5, Session 1997-98, The Stationery Office, London.

National Audit Office (1998) "The Private Finance Initiative: The First Four Design, Build, Finance and Operate Roads Contracts", Report of Comptroller and Auditor General, HC 476, Session 1997-98, The Stationery Office, London.

National Audit Office (2000) "The Financial Analysis for the London Underground Public Private Partnership", House of Commons Paper 54, Session 2000-01, The Stationary Office, London, 2000.

National Audit Office (2002a) "PFI Refinancing Update", Report of Comptroller and Auditor General, HC 1288, Session 2001-02, The Stationery Office, London.

National Audit Office (2002b) "The Public Private Partnership for National Air Traffic Services $L t d "$, Report by the Comptroller and Auditor General, HC 1096, Session 2001-02, The Stationery Office, London

National Audit Office (2004a) London Underground Public Private Partnerships: were they good deals? Report of Comptroller and Auditor General, HC 645, Session 2003-04, The Stationary Office, London.

National Audit Office (2004b) London Underground: are the Public Private Partnerships likely to work successfully? Report of Comptroller and Auditor General, HC 644, Session 200304, The Stationary Office, London. 
National Audit Office (2005) "The refinancing of the Norfolk and Norwaich PFI hospital: how the deal can be viewed in the light of refinancing", Report by the Comptroller and Auditor General, HC 78, Session 20005-06, The Stationery Office, London.

National Audit Office (2006) "Update on PFI debt refinancing and the PFI equity market", Report by the Comptroller and Auditor General, HC 1040, Session 2006-07, The Stationery Office, London.

National Audit Office (2009) Department of Transport: Failure of Metronet, Report of Comptroller and Auditor General, HC 512, Session 2008-09, The Stationery Office, London.

National Audit Office (2010) Financing PFI projects in the credit crisis and the Treasury's response, Report of Comptroller and Auditor General, HC 287, Session 2010-11, The Stationery Office, London.

$\mathrm{Ng}, \mathrm{A}$ and Loosemore. M (2007), 'Risk allocation in the private provision of public infrastructure', International Journal of Project Management, Vol. 25(1), pp 66-76.

OECD (2001), OECD Best Practices for Budget Transparency, PUMA/SBO(2000)6/FINAL, OECDD, Paris, May, accessed $29^{\text {th }}$ August 2012 at http://search.oecd.org/officialdocuments/publicdisplaydocumentpdf/?cote=PUMA/SBO( $\underline{2000) 6 / \text { FINAL\&docLanguage }=E n}$

OECD (2011) Better economic regulation: the role of the regulator Discussion paper 2011 .03, output paper from roundtable December 2010 International Transport Forum, OECD, Paris.

Pollock, A and Price, D (2004), Public risk for private gain? The public audit implications of risk transfer and private finance, Unison, London.

Pollock, A., and Price, D. (2008) "Has the NAO audited risk transfer in operational Private Finance Initiative schemes?" Public Money and Management, Vol. 28, No. 3, pp173-78.

Public Accounts Committee (2010) Financing PFI projects in the credit crisis and the Treasury's response, Ninth report, HC 553, Session 2010-11, The Stationery Office, London.

PwC (1999) London Underground PPP - Briefing Document, PwC, London.

PwC (2000) London Underground PPP: Methodology for Preparing the Public Sector Comparator, PwC, London.

PwC (2004) Developing Public Private Partnerships in New Europe, PWC, London

PWC (2005), Delivering the PPP promise: a review of PPP issues and activity, PWC, London.

Quiggin, J (2005), 'Public Private Partnerships: Options for Improved Risk allocation', The Australian Economic Review, Vol. 38(4), pp 445-450. 
Shaoul, J. (2002) "A Financial Appraisal of London Underground Public Private Partnership", Public Money and Management, Vol. 22, No.2, pp53-60.

Shaoul, J. (2003) "Financial analysis of the National Air Traffic Services Public Private Partnership", Public Money and Management, Vol. 3, No. 23, pp185-194.

Shaoul, J. (2004) "Railpolitik: The financial realities of operating Britain's National Railways", Public Money and Management, Vol. 24, No. 1, pp 27-36.

Shaoul, J. (2006) "The cost of operating Britain's privatised railways", Public Money and Management, Vol. 26, No.3, pp151-158.

Shaoul, J. (2010) "A review of transport public-private partnerships in the UK" in Hodge, G. A., Greve, C. and Boardman, A. E. (eds) International Handbook on public-private partnerships, Edward Elgar Publishing, Cheltenham, UK.

Shaoul, J., Stafford, A. and Stapleton, P. (2006) "Highway Robbery? A financial analysis of the Design, Build, Financing and Operation (DBFO) in UK Roads", Transport Reviews, Vol. 26, No. 3, pp257-274

Shaoul, J., Stafford, A, Stapleton, P. (2007a) "Evidence based policies and the meaning of success: the case of a road built under Design Build Finance and Operate", Evidence and Policy, Vol. 3, No. 2, pp159-179.

Shaoul, J., Stafford, A, Stapleton, P. (2007b) "Private control over public policy: financial advisors and the private finance initiative", Policy and Politics, Vol. 35, No. 3, pp479496.

Shaoul, J., Stafford, A., Stapleton, P., and Macdonald, P. (2008a) "Financial black holes: accounting for privately financed roads in the UK", ICAS, Edinburgh.

Shaoul, J., Stafford, A., and Stapleton, P. (2008b) "The cost of using private finance to build, finance and operate the first 12 NHS hospitals in England", Public Money and Management, Vol. 28, No. 2, pp101-108.

Shaoul, J., Stafford, A. \& Stapleton, P. (2011), 'Bridging the gap? Financing the Dartford and Skye bridges in the UK', Public Money and Management, Vol. 31, Issue 1, pp 51-58.

Silva, G. F. (2000) "Toll Roads: Recent Trends in Private Participation", Private Sector and Infrastructure Network, Note Number 224, World Bank, Washington DC.

Standard and Poor's (2003) Public Finance/Infrastructure Finance: Credit Survey Of The UK Private Finance Initiative And Public-Private Partnerships, Standard and Poor's, London.

Strategic Rail Authority (2003), "Strategic Plan 2003: platform for progress", Strategic Rail Authority, London.

Taylor, G. (2005) "Major road works ahead: 10 years of the UK private finance initiative roads program", in Standard and Poor's, Public Private Partnerships: global credit survey 2005, London. 
Transport Select Committee (2004) "The future of the railway", seventh report of session 2003-04, Vol. 1, HC 145-1, (The Stationery Office, London).

Transport Select Committee (2006) "Passenger Rail Franchising", HC 1354, Fourteenth Report, Session 2005-06, The Stationery Office, London

Treasury (2003) PFI Meeting the Investment Challenge, HM Treasury, London

Treasury (2006), PFI: strengthening long-term partnerships, The Stationery Office, London. 
